\title{
Pengaruh Good Corporate Governance dan Karakteristik Perusahaan Terhadap Pengungkapan Corporate Social Responsibility
}

\author{
Aurellia Adi Leksono \\ Universitas Katolik Soegijapranata \\ aurel.leksono@gmail.com \\ Sansaloni Butar Butar \\ Universitas Katolik Soegijapranata \\ sansaloni@unika.ac.id
}

\begin{abstract}
This study examine the role of good corporate governance (GCG) and firm characteristics to expand corporate social responsibility (CSR) disclosure. CSR disclosure is measured by fraction of total items reported in Sustainability Report to 58 items index released by Global Reporting Initiative. Samples are collected from listed companies in BEI (Bursa Efek Indonesia) and have been participated in Indonesian Sustainability Report Award (ISRA during 2014-2016. As much as 22 companies have complete data for further analysis. Using multiple regression analysis, results showed that profitability have a positive effect on CSR disclosure and become the only accepted hypothesis in this research; size of board of commissioner, company size, and leverage have no effect on CSR disclosure; while audit committee meeting frequency have negative effect on CSR disclosure.
\end{abstract}

Keyword: corporate social responsibility, sustainability report, ISRA award, GRI standard, audit committee meeting frequency

\begin{abstract}
Abstrak
Studi ini menguji peranan tata kelola perusahaan dan karakteristik perusahaan dalam meningkatkan pengungkapan tanggung-jawab sosial perusahaan (CSR). Tata kelola perusahaan dalam penelitian ini adalah frekuensi pertemuan komite audit dan ukuran dewan komisaris. Pengungkapan CSR diukur dengan membandingkan jumlah item pengungkapan yang dilaporkan dalam Sustainability Report dengan 58 item yang dikeluarkan Global Reporting Initiative (GRI). Sementara karakteristik perusahaan yang menjadi perhatian adalah ukuran perusahaan, profitabilitas, dan tingkat utang.. Sampel dalam penelitian diperoleh dari perusahaan-perusahaan yang terdaftar di Bursa Efek Indonesia yang mengambil bagian dalam Indonesian Sustainability Report Award (ISRA) pada tahun 2014 hingga 2016. Sebanyak 22 perusahaan yang dapat digunakan untuk analisis lanjutan. Menggunakan analisis regresi linier berganda, hasil penelitian menunjukkan bahwa profitabilitas berpengaruh positif terhadap pengungkapan CSR dan merupakan satu-satunya hipotesis yang diterima di dalam penelitian ini; Ukuran dewan komisaris, ukuran perusahaan, dan leverage tidak berpengaruh terhadap pengungkapan CSR; sedangkan frekuensi pertemuan komite audit berpengaruh negatif terhadap pengungkapan CSR.
\end{abstract}

Kata kunci : tanggung-jawab sosial perusahaan, laporan keberlanjutan, penghargaan ISRA, pedoman GRI, frekuensi pertemuan komite audit 


\section{PENDAHULUAN}

Pada masa sekarang ini, keberlanjutan dari sebuah perusahaan tidak dinilai dari kondisi keuangannya saja, namun juga dilihat dari cara perusahaan tersebut dalam mengelola masyarakat dan lingkungan sekitarnya. Hal ini didukung dengan bertambah banyaknya perusahaan yang telah melakukan kegiatan Corporate Social Responsibility (CSR) sebagai bentuk tanggung jawab perusahaan terhadap sosial dan lingkungan. Tidak hanya melakukan kegiatan CSR, beberapa perusahaan juga mengeluarkan Laporan Keberlanjutan atau Sustainability Report (SR) di samping Laporan Tahunan yang menjadi kewajiban setiap perusahaan yang terdaftar di Bursa Efek Indonesia (BEI).

SR merupakan bentuk laporan yang bersifat sukarela (voluntary)sebagai bentuk tanggung jawab sosial dan lingkungan. SR sangat diperlukan agar para pemangku kepentingan (stakeholders)dan masyarakat, mengetahui segala bentuk tanggung jawab perusahaan kepada masyarakat dan lingkungan (Sari dan Marsono, 2013). SR mempunyai fungsi untuk melaporkan kegiatan CSR secara rinci. Selain itu, dalam SR juga disebutkan jumlah limbah yang dihasilkan dari produksi perusahaan, cara pengolahan limbah tersebut, kebijakan penggunaan energi perusahaan, hingga hal-hal yang berhubungan dengan tenaga kerja.

Hingga saat ini, belum ada definisi CSR atau SR yang dapat diterima secara umum (Dilling, 2009). Di Indonesia sendiri telah dikeluarkan UU no. 40 tahun 2007 yang menjelaskan bahwa perusahaan dalam menjalankan kegiatan usaha yang berhubungan dengan sumber daya alam wajib melakukan tanggung jawab sosial dan lingkungan. Namun, belum ada peraturan yang mengharuskan perusahaan-perusahaan untuk mengeluarkan SR. Selain itu, belum ada penerapan indeks saham khusus untuk perusahaan-perusahaan yang telah menerapkan CSR. Hal ini menjadi kemungkinan penyebab perusahaan tidak merasa terdorong untuk mengeluarkan SR maupun melakukan kegiatan CSR.

Akibat tidak adanya dampak positif yang dirasakan perusahaan dalam mengeluarkan SR maupun melakukan kegiatan CSR maka banyak perusahaan yang merasa hal-hal tersebut cukup dilakukan sekedarnya saja atau bahkan dianggap sebagai beban yang dapat mengurangi laba perusahaan dalam jangka pendek tanpa mau memikirkan (1) dampak produksi perusahaan terhadap masyarakat dan lingkungan serta (2) dampak jangka panjang yang akan didapat dari melakukan kegiatan CSR dan menerbitkan SR.

Penelitian ini menganalisis pengaruh tata kelola perusahaan (GCG) dan karakteristik perusahaan terhadap pengungkapan tanggung-jawab sosial perusahaan (CSR). Penelitian ini menggunakan sampel perusahaan yang mengikuti ISRA tahun 2014-2016 dan menggunakan pedoman GRI-G4. Sejak tahun 2005, National Center for Sustainability Reporting (NCSR) mengadakan acara penghargaan Indonesia Sustainability Report Award (ISRA) bagi perusahaan yang menerbitkan SR sesuai dengan pedoman yang mengacu pada rerangka pelaporan yang dikeluarkan oleh Global Reporting Initiative (GRI). Pengukuran variabel CSR dalam penelitian ini mengacu pada kelengkapan jumlah item yang diungkapkan secara umum oleh manajemen dalam SR ditinjau dari pedoman GRI-G4.

\section{LANDASAN TEORI}

\section{Corporate Social Responsibility (CSR)}

Tanggung Jawab Sosial Perusahaanatau Corporate Social Responsibility (CSR) merupakan suatu bentuk kegiatan yang dilakukan oleh perusahaan yang bertujuan agar dapat mengurangi dampak buruk produksinya. Kegiatan ini sedang marak dilakukan oleh perusahaan-perusahaan di berbagai belahan negara mengingat semakin parahnya pemanasan global yang terjadi. Di Indonesia sendiri, hal ini ditandai dengan munculnya UU no 40 tahun 
2007 yang mengatur tentang kewajiban tanggung jawab sosial dan lingkungan yang harus dilakukan oleh perusahaan yang kegiatan usahanya berhubungan dengan sumber daya alam.

Meskipun fenomena pengungkapan CSR telah muncul lebih dari 2 (dua) dekade, namun penelitian tentang praktik pengungkapan CSR sepertinya terpusat di Amerika Serikat, Inggris, dan Australia. Penelitian yang dilakukan di negara lain seperti Kanada, Jerman, Jepang, Selandia Baru, Malaysia, Indonesia dan Singapura masih terbilang sedikit (Hackston dan Milne, 1996). Berbagai penelitian yang telah dilakukan pun menunjukkan keaneka-ragaman hasil. Keaneka-ragaman hasil tersebut sebagian disebabkan karena model yang dikembangkan merupakan model yang sangat sederhana dan pengukuran yang digunakan juga tidak konsisten (Sembiring, 2005).

Walaupun dengan keaneka-ragaman hasil yang ada, CSR telah menjadi isu penting yang semakin disorot karena menyangkut dampak perusahaan terhadap masyarakat dan lingkungannya. Terlebih lagi dengan semakin bertambahnya perusahaan-perusahaan baru dan pandangan internasional terhadap pencegahan pemanasan global yang semakin marak terjadi.

\section{Laporan Keberlanjutan atau Sustainability Report (SR)}

Laporan Keberlanjutan atau SR merupakan laporan yang berisi tentang hal-hal yang berhubungan dengan strategi keberlanjutan dari perusahaan tersebut. Strategi tersebut tercermin dalam kegiatan apa saja yang dilakukan oleh perusahaan untuk menjaga kesejahteraan karyawannya, pengelolaan polusi dan limbah yang dihasilkan dari proses produksi perusahaan, serta CSR yang dilakukan bagi kepentingan masyarakat dan lingkungan.

Hingga sekarang ini, belum ada peraturan di Indonesia yang mewajibkan perusahaan untuk mengeluarkan SR sehingga penerbitannya masih bersifat suka rela (Suryono dan Prastiwi, 2011). Hal ini dapat disebabkan karena tidak adanya definisi kegiatan CSR atau SR yang disepakati secara umum. Walaupun begitu, pembuatan SR dapat mengacu pada pedoman yang telah diakui secara internasionaldan telah digunakan di berbagai negara. GRI yang berpusat di Belanda merupakan organisasi independen yang menerbitkan pedoman laporan keberlanjutan. Versi terbaru dari pedoman GRI adalah G4 (fourth generation / generasi keempat), yang dikembangkan pada tahun 2013, berisi tentang prinsip pelaporan, standar pengungkapan, dan cara penerapan aturan GRI untuk pembuatan SR secara umum.

Walaupun belum ada peraturan wajib untuk mengeluarkan SR namun untuk mendorong penerbitan dan penggunaan laporan keberlanjutan oleh perusahan-perusahan di Indonesia maka lima organisasi terkemuka yaitu Komite Nasional Kebijakan Governance (KNKG), Forum for Corporate Governance in Indonesia (FCGI), Asosiasi Emiten Indonesia (AEI), Ikatan Akuntan Manajemen Indonesia (IAMI), dan Indonesian-Netherlands Association (INA) mendirikan organisasi non-profit bernama National Center for Sustainability Reporting (NCSR) pada tahun 2005. Melalui pendirian NCSR, diharapkan perusahaan-perusahaan dapat menunjukkan akuntabilitas dan transparansinya dalam melaksanakan tanggung-jawab sosial dan lingkunganmelalui laporan keberlanjutan yang diterbitkan berdasarkan pedoman pelaporan yang dikeluarkan oleh GRI.

Sejak tahun 2006, NCSR menjadi anggota pemangku kepentingan GRI dan ditunjuk sebagai partner pelatihan laporan keberlanjutan untuk wilayah Indonesia, Malaysia, Thailand. NCSR juga mengadakan acara penghargaan yang dikenal dengan ISRA bagi perusahaanperusahaan yang menerbitkan dan melaporkan SR dengan acuan pedoman yang dikeluarkan oleh GRI. ISRA diadakan pertama kali pada tahun 2005 untuk mendorong kesadaran perusahaan-perusahan di Indonesia akan pentingnya SR. Sejak tahun 2012, NCSR mengikutsertakan perusahaan-perusahaan dari negara-negara Asia Tenggara yang lain. Dampak pendirian ISRA dapat terlihat dari peningkatan jumlah perusahaan yang mengeluarkan SR dan menjadi peserta dalam ISRA dari tahun ke tahun. Hingga kini, perusahaan-perusahaan 
yang menjadi peserta ISRA berasal dari perusahaan Badan Usaha Milik Negara (BUMN) dan perusahaan swasta.

\section{Tata Kelola Perusahaan atau Good Corporate Governance (GCG)}

Dalam rangka economy recovery, pemerintah Indonesia dan International Monetary Fund (IMF) memperkenalkan konsep GCG sebagai tata cara kelola perusahaan yang sehat (Sutedi, 2011). Konsep GCG ini tidak dapat hanya dipandang sebagai prinsip belaka namun harus diterapkan ke dalam setiap divisi perusahaan agar dapat meningkatkan profesionalisme dan kesejahteraan pemegang saham tanpa mengabaikan kepentingan stakeholders. Corporate Governance dibagi menjadi 2 (dua), internal dan eksternal. CG internal terdiri dari pemegang saham, direksi, dewan komisaris, manajer, karyawan/serikat pekerja, sistem remunerasi berdasar kinerja, dan komite audit. Sedangkan CGekternal terdiri dari kecukupan undangundang dan perangkat hukum, investor, institusi penyedia informasi, akuntan publik, intitusi yang memihak kepentingan publik bukan golongan, pemberi pinjaman, serta lembaga yang mengesahkan legalitas.

Ada 4 (empat) komponen utama yang diperlukan dalam konsep GCG, yaitu fairness, transparency, accountability, dan responsibility. Keempat komponen tersebut penting karena penerapan konsep GCG secara konsisten terbukti dapat meningkatkan kualitas laporan keuangan (Chtourou et al. 2001). Dari keempat prinsip GCG tersebut, dapat dirangkum menjadi dua kelompok. Tiga prinsip pertama (fairness, transparency, dan accountability) lebih memberikan penekanan terhadap kepentingan pemegang saham yang menilai perusahaan berdasarkan kondisi keuangannya. Sedangkan definisi dari komponen responsibility(pertanggungjawaban) adalah untuk memastikan perusahaan mematuhi peraturan-peraturan serta ketentuan yang berlaku serta nilai-nilai sosial yang lebih mengutamakan kepentingan stakeholders.

Dengan demikian, konsep GCG berkaitan erat dengan keberhasilan CSR perusahaan. Agar dapat berhasil, CSR harus terhubung dengan misi perusahaan secara keseluruhan dan strategi perusahaan. Hal ini termasuk hubungan internal yang efektif antara kegiatan CSR dengan CG (Dilling, 2010). Hal tersebut didukung pula Benn dan Bolton (2011) dengan menyatakan bahwa para stakeholder menuntut perusahaan untuk bertanggung-jawab atas lingkungan sekitar. Dengan demikian, CSR merupakan bukti adanya GCG terhadap tuntutan para stakeholder.

\section{Komite Audit}

Salah satu komponen GCG yang dibahas dalam penelitian ini adalah Komite Audit yang dibentuk oleh Dewan Komisaris. Fungsi Komite Audit adalah sebagai pembantu Dewan Komisaris, sehingga tidak memiliki otoritas eksekusi apa pun, kecuali apabila diberi kuasa khusus dari Dewan Komisaris untuk hal-hal tertentu. Peran dan tanggung jawab Komite Audit dikelompokkan menjadi 3 (tiga) yaitu financial reporting, $\mathrm{CG}$, dan risk and control management. Dalam bidang corporate governance Komite Audit harus dapat memastikan bahwa perusahaan telah melaksanakan dan mematuhi semua peraturan hukum serta aturan lainnya yang berlaku serta memastikan perusahaan menjalankan kegiatan usahanya secara etis dan bermoral. Kinerja yang baik dari Komite Audit dalam membantu Dewan Komisaris merupakan hal terpenting dalam memastikan implementasi GCG berjalan dengan baik, sehingga kecurangan atau keterpurukan bisnis dapat dihindari.

\section{Karakteristik Perusahaan}

Karakteristik perusahaan merupakan ciri-ciri khusus yang memebedakan sebuah perusahaan dengan perusahaan yang lain. Menurut Benardi et al. (2008) karakteristik perusahaan yang dihubungakan dengan luas pengungkapan dapat dikelompokkan menjadi 3 
(tiga) kategori: (1) Karakteristik yang berhubungan dengan struktur perusahaan yang mencakup variabel ukuran (size) perusahaan, leverage, dan porsi kepemilikan saham publik; (2) Karakteristik yang berhubungan dengan kinerja perusahaan yang mencakup variabel likuiditas dan profitabilitas; serta (3) Karakteristik yang berhubungan dengan pasar perusahaan yang dikaitkan dengan ukuran KAP (auditor) dan lingkup bisnis.

\section{Pengembangan Hipotesis}

\section{Komite Audit}

Penelitian ini dilakukan untuk menguji pengaruh GCG dan karakteristik perusahaan terhadap pengungkapan CSR. Salah satu variabel GCG dalam penelitian ini adalah komite audit yang ditunjuk oleh perusahaan sebagai penghubung antara dewan direksi dengan auditor eksternal, auditor internal, serta anggota independen yang memiliki tugas untuk memberikan pengawasan auditor dan memastikan manajemen melakukan tindakan korektif yang tepat terhadap hukum dan regulasi (Jati, 2009).

Kualitas komite audit dapat dipengaruhi oleh frekuensi pertemuan yang diadakan. Semakin berkualitas komite audit, maka mereka akan semakin dapat memahami makna strategis dari pengungkapan informasi dan apa yang dibutuhkan stakeholder secara luas. Oleh karena itu, semakin sering pertemuan komite audit diadakan maka akan semakin mampu untuk mendorong manajemen untuk melakukan praktik pengungkapan CSR (Suryono dan Prastiwi, 2011). Penelitian yang dilakukan oleh Suryono dan Prastiwi (2011) menunjukkan adanya pengaruh yang positif signifikan antara komite audit dengan pengungkapan CSR. Dengan demikian, maka hipotesis dalam penelitian ini adalah sebagai berikut :

\section{$H_{1}$ : Frekuensi Pertemuan Komite Audit berpengaruh positif terhadap pengungkapan CSR.}

\section{Ukuran Dewan Komisaris}

Dewan komisaris merupakan dewan yang bertugas mengawasi serta mengkaji dan memberi persetujuan atas keputusan yang dibuat oleh pihak manajemen atau direksi. Hal ini menyebabkan dewan komisaris mempunyai wewenang yang tinggi terhadap setiap keputusan yang diambil untuk kemajuan perusahaan. Dengan begitu, semakin besar ukuran dewan komisaris, semakin mudah pula untuk mengendalikan CEO dan pengawasan yang dilakukan akan semakin efektif (Hayuningtyas, 2007).

Apabila CEO semakin mudah dikendalikan, maka dewan komisaris secara tidak langsung dapat berperan-serta dalam mempengaruhi CEO untuk mengambil keputusan-keputusan yang mendukung keberlanjutan perusahaan. Penelitian yang dilakukan oleh Sembiring (2005) menemukan pengaruh yang positif signifikan antara jumlah dewan komisaris terhadap tingkat pengungkapan CSR. Hasil yang berpengaruh juga ditunjukkan oleh penelitian Sari dan Marsono (2013). Hal ini selaras dengan teori agensi yang menyatakan bahwa dewan komisaris, yang dianggap sebagai mekanisme pengendalian internal tertinggi, bertanggung jawab untuk memonitor tindakan manajemen puncak sehingga mengungkapkan tanggung jawab sosialnya. Terlebih lagi apabila dewan komisaris sudah mengetahui dan menyadari pentingnya kegiatan CSR untuk kelanjutan perusahaan. Dengan demikian, maka hipotesis dalam penelititan ini adalah sebagai berikut :

\section{H2: Ukuran Dewan Komisaris berpengaruh positif terhadap pengungkapan CSR.}

\section{Ukuran Perusahaan}

Semakin besar perusahaan mengindikasikan semakin besarnya kemungkinan perusahaan tersebut untuk dapat mengeluarkan saham, menjadi Perusahaan Terbuka (PT), dan terdaftar di BEI. Dengan begitu maka perusahaan harus mematuhi UU yang telah ditetapkan oleh 
pemerintah karena semakin besar pula dampak dan tanggung jawabnya baik terhadap lingkungan maupun masyarakat.

Pemerintah telah mengeluarkan UUno 40 tahun 2007 yang mengatur tentang kewajiban tanggung jawab sosial dan lingkungan yang harus dilakukan oleh perusahaan yang kegiatan usahanya berhubungan dengan sumber daya alam. Hal ini berarti setiap perusahaan yang telah terdaftar di BEI harus melakukan kegiatan CSR. Penelitian yang dilakukan oleh Sembiring (2005) menunjukkan terdapat pengaruh yang signifikan antara ukuran perusahaan dengan pengungkapan CSR. Hal ini juga didukung oleh hasil penelitian Dilling (2009) yang menunjukkan hasil yang sama walaupun Dilling menggunakan ukuran yang berbeda, yaitu jumlah segmen operasi (Suryono dan Prastiwi, 2011). Dengan demikian, maka hipotesis dalam penelitian ini adalah sebagai berikut :

H3: Ukuran Perusahaan berpengaruh positif terhadap pengungkapan CSR.

\section{Profitabilitas}

Hubungan profitabilitas terhadap pengungkapan CSR dapat dijelaskan dengan 2 (dua) argumen berbeda. Argumen pertama adalah semakin tinggi profitabilitas, maka pengungkapan CSR pun semakin banyak. Hal ini dikarenakan dengan profitabilitas yang tinggi, perusahaan dapat semakin banyak melakukan kegiatan-kegiatan CSR nya. Sedangkan argumen kedua adalah semakin rendah profitabilitas, maka semakin banyak pula pengungkapan CSR yang dilakukan. Hal ini didorong oleh motif perusahaan yang ingin menunjukkan citra baik perusahaan agar para pemangku kepentingan dapat menambah saham di perusahaan dan meningkatkan profitabilitas.

Meskipun terdapat perbedaan pendapat terhadap pengaruh profitabilitas pada pengungkapan CSR, namun beberapa hasil penelitian menemukan bahwa profitabilitas memiliki pengaruh signifikan positif terhadap kelengkapan pengungkapan laporan (Suryono dan Prastiwi (2011) dan Dilling (2009). Dengan demikian, maka hipotesis dalam penelitian ini adalah sebagai berikut :

H4: Profitabilitas berpengaruh positif terhadap pengungkapan CSR.

\section{Leverage}

Seperti profitabilitas, terdapat 2 (dua) argumen pula tentang pengaruh leverage terhadap pengungkapan CSR. Argumen pertama adalah semakin rendah tingkat leverage, maka pengungkapan CSR pun semakin banyak. Hal ini dikarenakan dengan leverage yang rendah, perusahaan mempunyai dana yang cukup untuk melakukan kegiatan-kegiatan CSR nya. Sedangkan argumen kedua adalah semakin tinggi tingkat leverage, maka semakin banyak juga pengungkapan CSR yang dilakukan. Hal ini didorong oleh motif perusahaan yang ingin menunjukkan citra baik perusahaan dengan tetap melakukan kegiatan CSR walaupun sedikit dan dengan tingkat leverage yang tinggi. Hal ini diharapkan akan memacu kesadaran para investor untuk dapat menanam saham dan menaikkan rating perusahaan.

Dengan demikian, hubungan antara tingkat utang dan pengungkapan CSR tidak dinyatakan dalam arah tertentu.

$\mathrm{H}_{5}$ : Leverage berpengaruh terhadap pengungkapan CSR.

\section{METODA PENELITIAN}

\section{Populasi dan Sampel Penelitian}

Populasi adalah seperangkat unit yang menjadi perhatian peneliti (Butar Butar, 2007). Populasi dalam penelitian ini adalah perusahaan yang menjadi peserta dalam ISRA tahun 20142016. ISRA diadakan dalam tahun yang berbeda dengan tahun penerbitan SR, sehingga laporan 
yang digunakan dalam penelitian ini diterbitkan oleh perusahaan pada tahun 2013-2015. Dengan demikian, laporan tahunan yang digunakan untuk mencari data karakteristik perusahaan adalah laporan yang diterbitkan pada tahun 2013-2015. Periode sampel yang digunakan dalam penelitian ini meliputi peserta ISRA pada tahun 2014-2016 karena standar GRI yang digunakan dalam penelitian ini adalah GRI-G4 yang baru diterbitkan pada tahun 2013.

Pemilihan sampel dilakukan dengan menggunakan metoda purposive sampling untuk mendapatkan sampel yang representative sesuai dengan kriteria yang ditentukan. Adapun kriteria sampel yang digunakan dalam penelitian adalah sebagai berikut :

1. Perusahaan yang menerbitkan SRdan menjadi peserta dalam ISRA pada tahun 2014-2016.

2. Perusahaan yang terdaftar di BEI dan menerbitkan laporan tahunan pada tahun 2013-2015.

3. Perusahaan yang menerbitkan SR menggunakan pedoman GRI-G4.

4. Memiliki data-data lengkap yang terkait dengan variabel-variabel yang digunakan dalam penelitian sehingga dapat digunakan untuk menganalisis pengaruh kinerja keuangan, ukuran perusahaan, dan corporate governance terhadap pengungkapan CSR.

Prosedur pemilihan sampel secara lengkap dapa dilihat pada tabel 1. Jumlah SR yang dikeluarkan oleh perusahaan pada tahun 2013-2015 yang menjadi peserta dalam ISRA pada tahun berikutnya adalah sebanyak 127 laporan dari 69 perusahaan. Berdasarkan kriteria di atas, maka jumlah sampel akhir yang memiliki data lengkap sehingga dapat digunakan dalam penelitian ini sebanyak 44 observasi dari 22 perusahaan.

\section{Tabel 1}

Prosedur Pengambilan Sampel

\begin{tabular}{|c|l|c|c|c|c|}
\hline No & \multicolumn{1}{|c|}{ Keterangan } & $\begin{array}{c}\text { ISRA } \\
2014\end{array}$ & $\begin{array}{c}\text { ISRA } \\
2015\end{array}$ & $\begin{array}{c}\text { ISRA } \\
2016\end{array}$ & Total \\
\hline 1. & $\begin{array}{l}\text { Perusahaan yang masuk dalam } \\
\text { ISRA tahun 2014-2016. }\end{array}$ & 35 & 37 & 55 & 127 \\
\hline 2. & $\begin{array}{l}\text { Perusahaan tidak terdaftar di } \\
\text { BEI. }\end{array}$ & $(19)$ & $(19)$ & $(40)$ & $(78)$ \\
\hline 3. & $\begin{array}{l}\text { Laporan SRtidak menggunakan } \\
\text { pedoman GRI-G4. }\end{array}$ & $(2)$ & $(1)$ & $(0)$ & $(3)$ \\
\hline 4. & $\begin{array}{l}\text { Laporan tahunan tidak } \\
\text { mencantumkan frekuensi } \\
\text { pertemuan Komite Audit }\end{array}$ & $(1)$ & $(1)$ & $(0)$ & $(2)$ \\
\hline \multicolumn{2}{|l|}{ Total sampel } & 13 & 16 & 15 & 44 \\
\hline
\end{tabular}

\section{Jenis dan Sumber Data}

Jenis data yang digunakan dalam penelitian ini adalah data sekunder yaitu SR dan laporan tahunan periode 2013-2015. Data yang digunakan merupakan SR yang didapat dari website masing-masing perusahaan dan database.globalreporting.org serta laporan tahunan yang didapat dari situs BEI yaitu www.idx.co.id. Data penelitian ini meliputi perusahaan yang terdaftar di ISRA Award pada periode 2014-2016 sehingga dianggap cukup mewakili kondisi perusahaan-perusahaan pelaku CSR yang berada di Indonesia.

\section{Definisi Operasional dan Pengukuran Variabel}




\section{variabel dependen}

Variabel dependen dalam penelitian ini adalah pengungkapan CSR yang diukur dari kelengkapan item yang diungkapkan di dalam SR. Dalam penelitian ini, daftar indikator pengungkapan yang digunakan mengacu padapedoman GRI-G4 dan merupakan item yang umum diungkapkan oleh manajemen dengan tujuan dapat memperoleh hasil penelitian yang konsisten walaupun dari sektor perusahaan yang berbeda. Pengukuran tabel ini dilakukan dengan menghitung jumlah item yang diungkapkan di dalam SR, kemudian dibagi dengan jumlah total item indikator pengungkapan menurut GRI-G4 sebesar 58 item (lihat lampiran), yang digambarkan dalam rumus berikut ini:

$$
\mathrm{CSR}=\frac{i}{n}
$$

Keterangan :

$\mathrm{CSR}=$ Pengungkapan CSR

$i \quad=$ Jumlah item pengungkapan yang dilaporkan

$n \quad=$ Jumlah total item pengungkapan

\section{a. Frekuensi Pertemuan Komite Audit}

Frekuensi Pertemuan Komite Audit merupakan jumlah pertemuan atau rapat yang diadakan oleh Komite Audit baik secara internal maupun dengan berbagai pihak untuk kemajuan perusahaan. Komite Audit dibentuk oleh Dewan Komisaris agar GCG dapat berjalan dengan baik. Pengukuran komite audit dalam penelitian ini serupa dengan penelitian Suryono dan Prastiwi (2011) serta Sari dan Marsono (2013) yaitu dengan jumlah rapat dalam setahun.

\section{b. Ukuran Dewan Komisaris}

Ukuran Dewan Komisaris adalah jumlah anggota dewan komisaris di dalam suatu perusahaan. Dewan Komisaris bertugas untuk mengawasi dan menyetujui setiap keputusan yang dibuat oleh manajemen, sehingga semakin besar ukuran dewan komisaris maka pengawasan yang dilakukan akan semakin efektif. Dalam penelitian ini ukuran dewan komisaris diukur dengan jumlah anggota Dewan Komisaris seperti dalam penelitian Sembiring (2005).

\section{c. Ukuran perusahaan}

Ukuran perusahaan adalah skala besar kecilnya suatu perusahaan yang dapat diukur dengan berbagai cara, salah satunya dari asset yang dimiliki oleh perusahaan tersebut. Semakin besar sebuah perusahaan, maka asset yang dimiliki akan semakin banyak. Dalam penelitian ini ukuran perusahaan diukur dengan log total aset.

\section{d. Profitabilitas}

Profitabilitas adalah salah satu komponen karakteristik perusahaan yang dianggap dapat mempengaruhi kegiatan CSR yang dilakukan oleh sebuah perusahaan. Serupa dengan penelitian Suryono dan Prastiwi (2011) serta Sari dan Marsono (2013), profitabilitas dalam penelitian ini diukur dengan menggunakan ROA yaitu rasio laba bersih terhadap total asset.

\section{e. Leverage}

Leverage yaitu hutang yang dimiliki oleh perusahaan. Leverage dapat berperan sebagai penghambat atau justru mendorong sebuah perusahaan untuk melakukan kegiatan CSR. Pengukuran leverage yang digunakan dalam penelitian ini serupa dengan penelitian Sembiring (2005), Suryono dan Prastiwi (2011) serta Sari dan Marsono (2013) yaitu rasio hutang terhadap modal atau DER. 


\section{Analisis Regresi Linier Berganda}

Hipotesis yang akan diuji dalam penelitian ini yaitu pengaruh mekanisme GCG dan karakteristik perusahaan terhadap pengungkapan CSR dengan menggunakan analisis regresi linier berganda. Model yang digunakan untuk menguji pengaruh variabel-variabel dalam penelitian ini adalah:

$$
\mathrm{CSR}=\alpha+\beta_{1} \mathrm{FREKA}+\beta_{2} \mathrm{DEKOM}+\beta_{3} S I Z E+\beta_{4} \mathrm{ROA}+\beta_{5} \mathrm{DER}+\varepsilon
$$

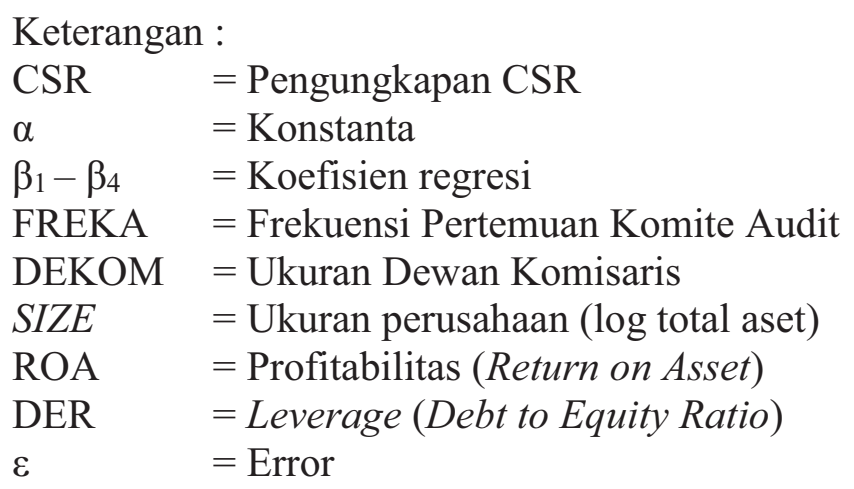

Tujuan penggunaan analisis regresi linear berganda adalah untuk mengetahui apakah terdapat hubungan variabel-variabel independen terhadap variabel dependen. Analisis ini juga dapat menentukan ukuran dan arah dari pengaruh variabel-variabel yang diuji. Sedangkan pengujian statistik yang dilakukan adalah:

\section{Uji Asumsi Klasik}

\section{a. Normalitas}

Tujuan dari uji normalitas adalah untuk menguji apakah dalam model regresi, variabel pengganggu atau reidual memiliki distribusi normal atau tidak. Seperti yang diketahui bahwa uji $\mathrm{T}$ dan $\mathrm{F}$ mengasumsikan bahwa nilai residual mengikuti distribusi normal. Kalau asumsi ini dilanggar maka uji statistik menjadi tidak valid untuk jumlah sampel kecil (Ghozali, 2011) Uji normalitas dalam penelitian ini menggunakan uji statistik Shapiro-Wilk karena sampel penelitian kurang dari 50 (lima puluh). Analisis statistik dilihat dari nilai signifikansi uji Shapiro-Wilk dengan batas signifikansi 0,05. Data residual dinyatakan normal apabila nilai signifikansi uji normalitas melebihi 0,05 .

\section{b. Multikoloniearitas}

Uji multikolonieritas bertujuan untuk menguji apakah dalam model regresi ditemukan adanya korelasi antar variabel bebas (independen). Model regresi yang baik seharusnya tidak menunjukkan adanya korelasi di antara variabel independen. Multikolonieritas dapat dilihat dari (1) nilai tolerance dan lawannya (2) variance inflation factor (VIF). Nilai tolerancemengukur variabilitas variabel independen terpilh yang tidak dijelaskan oleh variabel independen lainnya (Ghozali, 2011).

Nilai tolerance yang rendah sama dengan nilai VIF yang tinggi. Nilai cutoff yang umum untuk dapat menunjukkan adanya multikolonieritas adalah nilai tolerance $\leq 0.10$ atau sama dengan nilai VIF $\geq 10$. Peneliti harus menentukan tingkat koloniearitas yang masih dapat ditolerir. Sebagai contoh nilai tolerance $=0.10$ sama dengan tingkat kolonieritas 0.95 . Walaupun multikolonieritas dapat dideteksi dengan nilai tolerance dan VIF, tetapi kita masih tetap tidak mengetahui variabel-variabel mana saja yang saling berkorelasi (Ghozali, 2011).

\section{c. Heterokedastisitas}


Uji Heterokedastisitas bertujuan untuk menguji apakah terjadi ketidaksamaan variance dari residual antar pengamatan dalam suatu model regresi. Model regresi yang baik adalah model yang tidak mempunyai heterokedastisitas. Data crossection mempunyai potensi heterokedastisitas karena data ini menghimpun data yang mewakili berbagai ukuran.

Salah satu cara pengujian heterokedastisitas adalah dengan uji Glejser. Dalam penelitian ini, uji Glejser dilakukan dengan cara meregresi variabel independen terhadap nilai absolut unstandardized residual. Hasil uji heterokedastisitas akan dibandingkan dengan batas signifikansi 0,05. Apabila nilai absolut unstandardized residual melebihi 0,05 maka dapat disimpulkan tidak terdapat heterokedastisitas.

\section{d. Autokorelasi}

Tujuan dari uji autokorelasi adalah untuk mengetahui apakah dalam model regresi linear terdapat korelasi antara kesalahan pengganggu pada periode $t$ dengan kesalahan pengganggu pada periode sebelumnya. Model regresi yang baik adalah regresi yang bebas dari autokorelasi. Autokorelasi muncul karena observasi yang berurutan sepanjang waktu berkaitan satu sama lainnya. Karena itu permasalahan autokorelasi sering ditemukan pada data runtut waktu (time series).

Uji autokorelasi dalam penelitian ini menggunakan metoda uji Durbin-Watson (DW test). Nilai statistik DW (d) yang didapat akan dibandingkan dengan batas atas (dU) dan batas bawah (dL) yang terdapat pada tabel DW.

\section{HASIL DAN PEMBAHASAN}

\section{Statistik Deskriptif}

Dari pengolahan data yang telah dilakukan, didapati rata-rata item CSR yang diungkapkan oleh peserta ISRA yang terdaftar di BEI pada tahun 2013-2015 adalah 0,635 atau rata-rata 36 item dari 58 item yang menjadi indikator pengungkapan. Item-item yang paling sering diungkapkan antara lain yaitu komposisi pegawai (G4-10), pekerja terlindungi perjanjian kerja bersama (G4-11), upaya pencegahan resiko (G4-14), dan struktur tata kelola organisasi (G4-34). Sedangkan item yang hampir tidak pernah diungkapkan antara lain adalah jumlah informasi kritis yang disampaikan (G4-50), rasio kenaikan pembayaran kompensasi (G4-55), nominasi dan seleksi pejabat badan tata kelola (G4-40), sertakompetensi dan kinerja badan tata kelola (G4-43). Perusahaan yang paling banyak mengungkapkan item CSR nya adalah PT. Kideco Jaya Agung dengan tingkat pengungkapan 93\% pada tahun 2013.Sedangkan perusahaan yang paling sedikit mengungkapkan item CSR nya adalah PT. Bukit Asam dengan tingkat pengungkapan sebesar 52\% pada tahun 2014. Deskripsi mengenai variabel dependen dan variabel independen dapat dilihat pada tabel 2.

Berdasarkan pada tabel tersebut diketahui bahwa rata-rata frekuensi pertemuan yang diadakan oleh Komite Audit adalah sebesar 19,910. Hal ini menunjukkan bahwa rata-rata Komite Audit melakukan pertemuan sebanyak 19-20 kali dalam setahun. Ini berarti Komite Audit telah melakukan tanggung-jawabnya dengan mengadakan pertemuan minimal 1 kali sebulan atau 12 kali dalam setahun.Perusahaan yang paling banyak mengadakan pertemuan Komite Audit adalah PT. Bukit Asam dengan 59 kali pertemuan pada tahun 2014. Sedangkan perusahaan yang paling sedikit mengadakan pertemuan Komite Audit adalah PT. Indocement Tunggal Prakarsa pada tahun 2014-2015 serta PT. Bakrie Sumatera Plantations pada tahun 2015 yaitu sebanyak 4 kali pertemuan dalam setahun. 


\section{Tabel 2}

\begin{tabular}{|l|c|c|c|c|c|}
\hline & $\mathrm{N}$ & Minimum & Maksimum & Rata-Rata & Dev. Standar \\
\hline CSR & 34 & 0.520 & 0.930 & 0.635 & 0.099 \\
FREKA & 34 & 4.000 & 59.000 & 19.910 & 13.630 \\
DEKOM & 34 & 4.000 & 8.000 & 6.530 & 0.992 \\
SIZE & 34 & 12.920 & 14.800 & 13.824 & 0.540 \\
ROA & 34 & -0.030 & 0.310 & 0.083 & 0.081 \\
DER & 34 & 0.160 & 9.010 & 2.985 & 3.012 \\
& & & & & \\
\hline
\end{tabular}

Ukuran dewan komisaris yang diukur melalui jumlah anggota dewan komisaris memiliki rata-rata sebesar 6,530. Hal ini berarti jumlah rata-rata anggota dewan komisaris dari sampel perusahaan yang diteliti adalah 6-7 orang dalam sebuah perusahaan. Standar deviasi yang dimiliki ukuran dewan komisaris sangat kecil dibandingkan dengan nilai rata-rata yaitu 0,992 menunjukkan bahwa jumlah anggota dewan komisaris yang dimiliki oleh masing-masing perusahaan hampir sama. Anggota dewan komisaris terbanyak sejumlah 8 orang dimiliki oleh beberapa perusahaan yang bergerak pada sektor keuangan antara lain Bank CIMB Niaga pada tahun 2014-2015, Bank Permata pada tahun 2015, serta Bank Rakyat Indonesia pada tahun 2013. Sedangkan jumlah anggota dewan komisaris paling sedikit dimiliki oleh PT. Kideco Jaya Agung pada tahun 2013 sebanyak 4 orang.

Ukuran perusahaan yang diteliti dalam penelitian ini memiliki rata-rata sebesar 13,824 dengan nilai standar deviasi yang sangat kecil yaitu sebesar 0,540. Hal ini menunjukkan bahwa ukuran sampel perusahaan yang diteliti tidak terlalu berbeda. Ukuran perusahaan yang hampir sama juga dapat dilihat dari range antara nilai minimum dan nilai maksimum ukuran perusahaan yang hanya sebesar 1,880.PT. Kideco Jaya Agung merupakan perusahaan sampel dengan ukuran terkecil dalam penelitian ini dengan nilai SIZE sebesar 12,920.Sedangkan Bank Rakyat Indonesia menjadi perusahaan sampel dengan nilai ukuran terbesar yaitu 14,800.

Profitabilitas yang diukur melalui ROA masing-masing perusahaan memiliki rata-rata sebesar 0,083 dengan standar deviasi sebesar 0,081. Hal ini menunjukkan bahwa perusahaan sampel rata-rata memiliki keuntungan yang tidak terlalu besar yaitu sebesar 8,3\% dalam setahun. Angka negatif yang didapat dalam nilai minimum profitabilitas menunjukkan ada sampel perusahaan dalam penelitian ini yang mengalami kerugian pada tahun berjalan yaitu PT. Bakrie Sumatera Plantations pada tahun 2015 sebesar 3\%. Sedangkan profitabilitas terbesar dimiliki oleh PT. Kideco Jaya Agung dengan nilai ROA sebesar 31\% pada tahun 2013.

Sedangkan variabel leverage (DER) memiliki rata-rata sebesar 2,985 dengan standar deviasi di atas rata-rata yaitu sebesar 3,012 yang berarti bahwa variabel leverage cukup bervariasi. Hal ini juga dapat dilihat dari range antara nilai minimum leverage sebesar 0,160 dan nilai maksimum leverage sebesar 9,010. Secara rata-rata, ini berarti perusahaan sampel yang digunakan memiliki tingkat hutang yang cukup tinggi yaitu sebesar 29,8\%. Tingkat 
leverage terendah dimiliki oleh PT. Indocement Tunggal Prakarsa pada tahun 2015, sedangkan tingkat leverage tertinggi dimiliki oleh Bank Maybank Indonesia pada tahun 2015.

\section{Hasil Uji Asumsi Klasik}

\section{a) Uji normalitas}

Tabel 3 menampilkan hasil uji normalitas. Hasil awal uji normalitas dalam penelitian ini menunjukkan ketidak-normalan data dengan nilai Shapiro-Wilk sebesar 0,001. Maka dari itu, peneliti mengeluarkan 10 (sepuluh) outlier agar data penelitian dapat diolah.

Tabel 3

\section{Uji normalitas}

\begin{tabular}{|l|c|c|c|c|c|c|}
\hline & \multicolumn{3}{|c|}{ Kolmogorov-Smirnov $^{\mathrm{a}}$} & \multicolumn{3}{c|}{ Shapiro-Wilk } \\
\cline { 2 - 7 } & Statistic & $\mathrm{df}$ & Sig. & Statistic & df & Sig. \\
\hline $\begin{array}{l}\text { Unstandardized } \\
\text { Residual_after }\end{array}$ & 0.128 & 34.000 & 0.169 & 0.951 & 34.000 & 0.133 \\
\hline
\end{tabular}

\section{b) Uji multikolonieritas}

Tabel 4 menampilkan hasil uji multikolinearitas. Hasil uji multikolineritas dapat dilihat dari nilai tolerance dan VIF pada tabel uji multikolonieritas (tabel 4.4). Hasil tersebut menunjukkan bahwa seluruh nilai tolerance $\leq 1$ dan tidak ada nilai VIF yang $\geq 10$. Hal ini menunjukkan bahwa tidak ada masalah autokorelasi dalam data yang diteliti.

Tabel 4

\section{Uji multikolineritas}

\begin{tabular}{|c|c|c|c|c|c|c|}
\hline & \multirow[t]{2}{*}{ Model } & \multicolumn{2}{|c|}{ Unstandardized Coefficients } & \multirow{2}{*}{$\begin{array}{c}\begin{array}{c}\text { Standardized } \\
\text { Coefficients }\end{array} \\
\text { Beta }\end{array}$} & \multicolumn{2}{|c|}{ Collinearity Statistics } \\
\hline & & $\mathrm{B}$ & Std. Error & & Tolerance & VIF \\
\hline \multirow{6}{*}{1} & (Constant) & 1.050 & 0.601 & & & \\
\hline & FREKA & -0.002 & 0.001 & 0.774 & 0.774 & 1.291 \\
\hline & DEKOM & -0.003 & 0.021 & 0.518 & 0.518 & 1.932 \\
\hline & SIZE & -0.031 & 0.050 & 0.299 & 0.299 & 3.340 \\
\hline & $\mathrm{ROA}$ & 0.734 & 0.257 & 0.502 & 0.502 & 1.991 \\
\hline & DER & 0.009 & 0.009 & 0.328 & 0.328 & 3.050 \\
\hline
\end{tabular}

\section{c) Uji heteroskedastisitas}

Pengujian heteroskedastisitas dilakukan dengan menggunakan glejser test. Caranya adalah dengan melakukan regresi nilai absolut residual terhadap seluruh variabel independen yang digunakan dalam penelitian. Apabila salah satu dari variabel yang diuji menunjukkan nilai signifikansi yang kurang dari 0,05, maka ini menunjukkan telah terjadi pelanggaran asumsi heteroskedastistias. Perbaikan harus dilakukan sebelum pengujian lanjutan dilakukan. Ada beberapa cara yang dapat dilakukan untuk memastikan data yang digunakan bebas dari pelanggaran asumsi heteroskedastisitas. Salah satu cara adalah dengan melakukan transformasi data atas variabel-variabel yang digunakan dalam penelitian. Hasil uji heteroskedastisitas dapat 
dilihat pada tabel 5. Seluruh nilai signifikansi variabel telah melebihi batas signifikansi yaitu 0,05 sehingga dapat disimpulkan bahwa tidak terdapat heterokedastisitas pada variabel-variabel yang digunakan dalam penelitian ini. Dengn demikian pengujian hipotesis dapat dilanjutkan.

Tabel 5

Uji Heteroskedastisitas

\begin{tabular}{|l|c|c|c|c|c|}
\hline \multirow{2}{*}{ Model } & \multicolumn{2}{|c|}{ Unstandardized Coefficients } & Standardized Coefficients & \multirow{2}{*}{$\mathrm{t}$} & Sig. \\
\cline { 2 - 5 } & $\mathrm{B}$ & Std. Error & Beta & & \\
\hline (Constant) & 0.359 & 0.331 & & -084 & 0.288 \\
FREKA & -0.001 & 0.001 & -0.227 & 1.224 & 0.231 \\
DEKOM & 0.012 & 0.011 & 0.246 & 1.085 & 0.287 \\
SIZE & -0.029 & 0.027 & -0.313 & -1.047 & 0.304 \\
ROA & 0.284 & 0.141 & 0.463 & 2.007 & 0.054 \\
DER & 0.003 & 0.005 & 0.189 & 0.663 & 0.513 \\
\hline
\end{tabular}

\section{d) Uji autokorelasi}

Hasil uji autokorelasi dalam penelitian ini dilihat dari nilai DW pada tabel tabel 3 yaitu sebesar 1,934. Penelitian ini menggunakan 5 variabel independen dan 34 sampel penelitian. Menurut tabel DW, maka nilai dL adalah 1,144 dan nilai dU 1,808. Hal ini menunjukkan tidak terdapat masalah autokorelasi.

Tabel 6

\section{Uji Autokorelasi}

\begin{tabular}{|l|r|r|r|r|r|}
\hline Model & \multicolumn{1}{|c|}{$\mathrm{R}$} & R Square & \multicolumn{1}{|c|}{$\begin{array}{c}\text { Adjusted R } \\
\text { Square }\end{array}$} & $\begin{array}{l}\text { Std. Error of the } \\
\text { Estimate }\end{array}$ & Durbin-Watson \\
\hline 1 & $0.618^{\mathrm{a}}$ & 0.382 & 0.272 & 0.084 & 1.934 \\
\hline
\end{tabular}

\section{Analisis dan Pembahasan}

Pengaruh variabel independen terhadap variabel dependen secara individu dapat dilihat pada tabel 7. Penelitian ini menggunakan hipotesis dua arah, sehingga seluruh nilai signifikansi yang terdapat dalam tabel 7 akan dibagi 2 (dua). Hipotesis akan diterima apabila hasil akhir nilai signifikansi (sig./2) tidak melebihi batas signifikansi yang ditentukan. Dengan batas 
signifikansi 0,050 maka 4 (empat) hipotesis dalam penelitian ini ditolak dan 1 (satu) hipotesis diterima.

Hipotesis pertama dalam penelitian ini adalah terdapat pengaruh positif antara frekuensi pertemuan Komite Audit terhadap pengungkapan CSR. Dalam tabel 7, nilai t yang didapat adalah -2,023 dengan nilai sig./2 sebesar 0,027. Dengan batas signifikansi 0,050 maka variabel frekuensi pertemuan Komite Audit berpengaruh negatif terhadap pengungkapan CSR.

Hipotesis kedua dalam penelitian ini adalah terdapat pengaruh positif antara ukuran Dewan Komisaris terhadap pengungkapan CSR. Dalam tabel 7, nilai t yang didapat adalah $-0,140$ dengan nilai signifikansi 0,445 . Dengan batas signifikansi 0,050 maka variabel frekuensi ukuran Dewan Komisaris tidak berpengaruh terhadap pengungkapan CSR.

Tabel 7

\section{Hasil Analisis Regresi}

\begin{tabular}{|l|c|c|c|c|c|c|c|}
\hline \multirow{2}{*}{ Model } & \multicolumn{2}{|c|}{$\begin{array}{c}\text { Unstandardized } \\
\text { Coefficients }\end{array}$} & $\begin{array}{c}\text { Standardized } \\
\text { Coefficients }\end{array}$ & \multirow{2}{*}{$\mathrm{t}$} & Sig. & Sig. / 2 & Hasil \\
\cline { 2 - 4 } & $\mathrm{B}$ & Std. Error & Beta & & & & \\
\hline (Constant) & 1.050 & 0.601 & & 1.747 & 0.092 & 0.046 & \\
FREKA & -0.002 & 0.001 & -0.341 & -2.023 & 0.053 & 0.027 & Ditolak \\
DEKOM & -0.003 & 0.021 & -0.029 & -0.140 & 0.889 & 0.445 & Ditolak \\
SIZE & -0.031 & 0.050 & -0.172 & -0.632 & 0.532 & 0.266 & Ditolak \\
ROA & 0.734 & 0.257 & 0.599 & 2.858 & 0.008 & 0.004 & Diterima \\
DER & 0.009 & 0.009 & 0.281 & 1.085 & 0.287 & 0.144 & Ditolak \\
\hline
\end{tabular}

Hipotesis ketiga dalam penelitian ini adalah terdapat pengaruh positif antara ukuran perusahaan terhadap pengungkapan CSR. Dalam tabel 7, nilai t yang didapat adalah $-0,632$ dengan nilai signifikansi 0,266. Dengan batas signifikansi 0,050 maka variabel ukuran perusahaan tidak berpengaruh terhadap pengungkapan CSR.

Hipotesis keempat dalam penelitian ini adalah terdapat pengaruh positif antara profitabilitas terhadap pengungkapan CSR. Dalam tabel 7 , nilai t yang didapat adalah 2,858 dengan nilai signifikansi 0,004. Dengan batas signifikansi 0,050 maka variabel profitabilitas berpengaruh positif terhadap pengungkapan CSR.

Hipotesis kelima dalam penelitian ini adalah terdapat pengaruh negatif antara leverage terhadap pengungkapan CSR. Dalam tabel 7, nilai t yang didapat adalah 1,085 dengan nilai signifikansi 0,144. Dengan batas signifikansi 0,050 maka variabel leverage tidak berpengaruh terhadap pengungkapan CSR.

\section{Frekuensi Pertemuan Komite Audit}

Dari hasil pengujian hipotesis, diketahui bahwa hipotesis pertama ditolak. Hal ini disebabkan oleh nilai $\mathrm{t}$ yang negatif dari frekuensi pertemuan Komite Audit (FREKA), sehingga walaupun nilai sig./2 yang didapat menunjukkan bahwa FREKA berpengaruh secara signifikan terhadap pengungkapan CSR namun arah yang ditunjukkan adalah negatif.

Dalam penelitian ini, sampel perusahaan yang diteliti berasal dari sektor usaha campuran, sehingga indikator pengukuran CSR yang digunakan adalah indikator pengungkapan yang umum dilakukan oleh manajemen dengan berpedoman pada GRI-G4. Item-item pengungkapan umum tersebut umumnya telah dilaporkan dalam laporan tahunan perusahaan. Hal ini dapat menjadi penyebab item-item tersebut tidak dilaporkan kembali di dalam SR. 
Dengan demikian, Komite Audit dapat memilih untuk tidak mendorong manajemen untukmelaporkan kembali item-item yang umum tersebut di dalam SR.. Maka dari itu, frekuensi pertemuan Komite Audit berpengaruh negatif terhadap banyaknya pengungkapan CSR yang dilakukan oleh perusahaan.

\section{Ukuran Dewan Komisaris}

Dari hasil pengujian hipotesis, diketahui bahwa hipotesis kedua ditolak. Hal ini menunjukkan ukuran Dewan Komisaris (DEKOM) tidak berpengaruh terhadap pengungkapan CSR yang dilakukan oleh perusahaan. Ini berarti banyaknya jumlah anggota Dewan Komisaris dalam suatu perusahaan tidak berpengaruh terhadap pengungkapan CSR yang dilakukan oleh perusahaan. Dalam penelitian ini, hal tersebut dibuktikan oleh PT. Kideco Jaya Agung yang memiliki tingkat pengungkapan sebesar 93\% walaupun dengan ukuran Dewan Komisaris terkecil yaitu sebanyak 4 orang. Berkebalikan dengan beberapa perusahaan dari sektor keuangan yang memiliki anggota Dewan Komisaris terbanyak sejumlah 8 orang, namun tingkat pengungkapannya hanya sebesar 59\% antara lain yaitu Bank CIMB Niaga, Bank Negara Indonesia, dan Bank Permata. Maka dari itu, ukuran Dewan Komisaris tidak berpengaruh terhadap banyaknya pengungkapan CSR yang dilakukan oleh perusahaan. Hasil ini tidak sesuai dengan penelitian Sembiring (2005) yang menyatakan bahwa ukuran Dewan Komisari berpengaruh positif walaupun dengan cara pengukuran yang sama, namun dapat mendukung hasil penelitian yang telah dilakukan oleh Widyatama (2014) serta Nugroho dan Yulianto (2015).

\section{Ukuran Perusahaan}

Dari hasil pengujian hipotesis, diketahui bahwa hipotesis ketiga ditolak. Hal ini menunjukkan ukuran perusahaan (SIZE) tidak berpengaruh terhadap pengungkapan CSR yang dilakukan oleh perusahaan. Ini berarti besar-kecilnya ukuran perusahaan tidak mempengaruhi pengungkapan CSR. Hal ini bisa disebabkan kriteria pemilihan sampel penelitian yang spesifik yaitu perusahaan-perusahaan yang terdaftar di BEI dan menjadi peserta ISRA. Akibatnya jumlah sampel perusahaan yang diteliti menjadi tidak terlalu berbeda seperti yang dapat dilihat pada rata-rata tabel statistik deskriptif sehingga variabel ukuran perusahaan menjadi tidak berpengaruh terhadap pengungkapan CSR. Sedangkan nilai minus yang didapat pada hasil uji t menunjukkan arah negatif yang berarti bahwa semakin kecil perusahaan dalam penelitian ini maka semakin banyak pengungkapan CSR yang dilakukan. Hal ini menunjukkan bahwa perusahaan-perusahaan yang lebih kecil justru lebih terbuka dalam pengungkapan CSR terhadap para stakeholder dan masyarakat umum. Maka dari itu, ukuran perusahaan tidak berpengaruh terhadap banyaknya pengungkapan CSR yang dilakukan oleh perusahaan. Hasil penelitian ini sesuai dengan penelitian Sari dan Marsono (2013) yang menyatakan bahwa ukuran perusahaan tidak berpengaruh terhadap pengungkapan CSR.

\section{Profitabilitas}

Dari hasil pengujian hipotesis, diketahui bahwa hipotesis keempat diterima. Hal ini menunjukkan profitabilitas yang diukur dengan rasio ROA berpengaruh positif terhadap pengungkapan CSR yang dilakukan oleh perusahaan. Hal ini menyebabkan profitabilitas menjadi satu-satunya variabel dalam penelitian ini yang hasil pengujiannya menunjukkan arah yang sesuai dengan hipotesis yang diajukan, sehingga hipotesis keempat menjadi satu-satunya hipotesis yang diterima dalam penelitian ini. Ini menunjukkan bahwa perusahaan yang memiliki profit yang tinggi mempunyai cukup dana untuk melakukan kegiatan-kegiatan CSR. Hasil ini konsisten dengan Prastiwi (2011). 


\section{Leverage}

Dari hasil pengujian hipotesis, diketahui bahwa hipotesis kelima ditolak. Hal ini menunjukkan variabel leverage yang diukur melalui rasio DER dalam penelitian ini tidak berpengaruh terhadap pengungkapan CSR yang dilakukan oleh perusahaan.

Variabel leverage dalam penelitian ini justru menunjukkan arah yang berbeda dari hipotesis yang telah diajukan walaupun tidak berpengaruh secara signifikan terhadap pengungkapan CSR yang dilakukan oleh sampel perusahaan yang diteliti. Walaupun variabel leverage dalam penelitian ini memiliki hasil yang positif, namun nilai sig./2 sebesar 0,144 yang melebihi batas signifikansi 0,050 menunjukkan bahwa variabel leverage tetap tidak berpengaruh terhadap pengungkapan CSR yang dilakukan oleh sampel perusahaan yang diteliti.

Nilai positif 1,085 yang didapat dalam tabel 7 menunjukkan bahwa semakin banyak tingkat hutang yang dimiliki perusahaan maka semakin tinggi pengungkapan CSR. Hal ini mendukung argumen yang menyatakan bahwa semakin tinggi tingkat leverage, maka semakin banyak juga pengungkapan CSR yang dilakukan karena didorong oleh motif perusahaan yang ingin menunjukkan citra baik perusahaan dengan tetap melakukan kegiatan CSR walaupun dengan tingkat leverage yang tinggi.

Di samping itu, penelitian ini menggunakan sampel perusahaan yang terdaftar di BEI dan menjadi peserta dalam ISRA award sehingga walaupun perusahaan tersebut masih mempunyai tingkat hutang yang tinggi pada masa sekarang, namun kegiatan CSR tetap dipandang sebagai kegiatan yang penting untuk keberlanjutan perusahaan sehingga mereka tetap melakukan kegiatan CSR. Hasil penelitian ini menambah dukungan bagi penelitian-penelitian sebelumnya yang telah dilakukan oleh Sembiring (2005), Suryono dan Prastiwi (2011), serta Sari dan Marsono (2013) yang menyatakan bahwa leverage tidak berpengaruh terhadap pengungkapan CSR.

\section{SIMPULAN}

Penelitian ini bertujuan untuk menguji pengaruh mekanisme GCG (komite audit dan dewan komisaris) serta karakteristik perusahaan (ukuran perusahaan, profitabilitas, leverage, dan aktivitas perusahaan) terhadap pengungkapan CSR pada perusahaan yang terdaftar di BEI dan menjadi peserta dalam ISRA 2014-2016. Perusahaan yang menjadi peserta ISRA 20142016 adalah sebanyak 127 perusahaan. Setelah melalui penyaringan kriteria penelitian dan mengeluarkan outlier, maka diperoleh 34 perusahaan yang memenuhi kriteria dan dapat digunakan dalam penelitian ini.

Berdasarkan hasil analisis dan pembahasan, maka kesimpulan yang dapat diambil dari penelitian ini adalah sebagai berikut:

1. Frekuensi pertemuan Komite Audit (FREKA) tidak berpengaruh terhadap pengungkapan CSR.

2. Ukuran Dewan Komisaris (DEKOM) tidak berpengaruh terhadap pengungkapan CSR. Hasil ini mendukung penelitian yang telah dilakukan oleh Widyatama (2014) serta Nugroho dan Yulianto (2015).

3. Ukuran perusahaan (SIZE) tidak berpengaruh terhadap pengungkapan CSR.Hasil ini mendukung penelitianyang telah dilakukan oleh Sari dan Marsono (2013).

4. Profitabilitas (ROA) berpengaruh positif terhadap pengungkapan CSR.Hasil ini mendukung penelitianyang telah dilakukan oleh Suryono dan Prastiwi (2011).

5. Leverage (DER) tidak berpengaruh terhadap pengungkapan CSR.Hasil ini mendukung penelitian yang telah dilakukan oleh Sembiring (2005), Suryono dan Prastiwi (2011), serta Sari dan Marsono (2013). 


\section{Keterbatasan dan Saran}

Keterbatasan dari penelitian ini terletak pada indeks pengukuran yang digunakan dalam penelitian ini yang hanya terbatas pada pengungkapan umum yang dilakukan oleh manajemen. Hal ini menyebabkan hasil penelitian menjadi kurang tepat sasaran karena tidak menggunakan indeks pengukuran yang berhubungan langsung dengan kegiatan CSR yang dilakukan perusahaan.

Sesuai dengan keterbatasan tersebut, maka disarankan untuk pengukuran CSR dalam penelitian yang selanjutnya sebaiknya juga dinilai dari standar pengungkapan yang sesuai dengan sektor-sektor usaha secara khusus yang dikeluarkan oleh GRI (sector disclosure) sehingga hasil penelitian dapat lebih akurat.

\section{DAFTAR PUSTAKA}

Benardi, M., Sutrisno, dan P. Assih. 2008. Faktor-Faktor yang Mempengaruhi Luas Pengungkapan dan Implikasinya terhadap Asimetri Informasi. Simposium Nasional Akuntansi XII

Benn, S., dan D. Bolton. 2011. Key Concepts in Corporate Social Responsibility. London: Sage Publications.

Butar Butar, S. 2015.Statistik untuk Ekonomi dan Bisnis (dilengkapi dengan aplikasi SPSS). Semarang: Universitas Katolik Soegijapranata

Chtourou, S.M., J. Bedard, dan L. Courteau. 2001. Corporate Governance and Earnings Management. Canada: Universite Laval.

Dilling, P.F.A. 2010. Sustainability Reporting in a Global Context: What are the Characteristics of Corporations that Provide High Quality Sustainability Reports: An Empirical Analysis. International Business \& Economics Research Journal 9 (1): 19-30.

Hackston, D dan M.J. Milne. 1996. Some Determinants of Social and Environmental Disclosures in New Zealand Companies. Accounting, Auditing, \& Accountability Journal 9 (1) : 77-108.

Jati, F. 2009. Pengaruh Struktur Corporate Governance terhadap Kinerja Perusahaan Manufaktur yang Terdaftar di Bursa Efek Indonesia. Universitas Gunadarma, Depok.

Nugroho, M.N., dan A. Yulianto. 2015. Pengaruh Profitabilitas dan Mekanisme Corporate Governance terhadap Pengungkapan CSR Perusahaan Terdaftar JII 2011-2013. Accounting Analysis Journal, 4 (1): 1-12.

Permanasari, W.I. 2010. Pengaruh Kepemilikan Manajemen, Kepemilikan Institusional, dan Corporate Social Responsibility terhadap Nilai Perusahaan. Program Sarjana Fakultas Ekonomi Universitas Diponegoro Semarang.

Sari, M.P.Y., dan Marsono. 2013. Pengaruh Kinerja Keuangan, Ukuran Perusahaan, dan Corporate Governance terhadap Pengungkapan Sustainability Report. Diponegoro Journal of Accounting 2 (3) : 1-10. 
Sembiring, E.R. 2005. Karakteristik Perusahaan dan Pengungkapan Tanggung Jawab Sosial : Studi Empiris pada Perusahaan yang Tercatat di Bursa Efek Jakarta. Simposium Nasional Akuntansi VIII.

Sutedi, A. 2011.Good Corporate Governance. Jakarta: Sinar Grafika.

Suryono, H., dan A. Prastiwi. 2011. Pengaruh Karakteristik Perusahaan dan Corporate Governance (CG) terhadap Praktik Pengungkapan Sustainability Report (SR) (Studi pada Perusahaan-Perusahaan yang Listed (Go-Public) di Bursa Efek Indonesia (BEI) Periode 2007-2009). Simposium Nasional AkuntansiXIV.

Triyanto, E. 2010. Faktor-Faktor yang Mempengaruhi Pengungkapan Tanggung Jawab Sosial (Studi Empiris Pada Perusahaan-Perusahaan yang Terdaftar di Bursa Efek Indonesia selama Tahun 2005-2008). Skripsi. Program Sarjana Fakultas Ekonomi Universitas Sebelas Maret Surakarta.

Widyatama, A. 2014. Good Corporate Governance dan Corporate Social Responsibility : Sebuah Tinjauan Empiris. Jurnal Akuntansi Aktual 2 (4) : 312-321 